\title{
Prediksi Kerawanan Wilayah Terhadap Tindak Pencurian Sepeda Motor Menggunakan Metode (S)ARIMA Dan CART
}

\author{
Pradita Eko Prasetyo Utomo*1, Azhari $\mathrm{SN}^{2}$ \\ ${ }^{1}$ Prodi S2 Ilmu Komputer; FMIPA UGM, Yogyakarta, Indonesia \\ ${ }^{2}$ Jurusan Ilmu Komputer dan Elektronika, FMIPA UGM, Yogyakarta, Indonesia \\ e-mail: *1'raditeko78@gmail.com, ${ }^{2}$ arisn@ugm.ac.id
}

\begin{abstract}
Abstrak
Pencurian kendaraan bermotor merupakan termasuk tindak kriminal yang paling sering terjadi di Indonesia. Pertumbuhan kendaraan bermotor khususnya sepeda motor cukup signifikan pada tiap tahunnya diiringi dengan semakin meningkatnya tindak pencurian sepeda motor pada tiap tahunnya. Selain itu, pertumbuhan penduduk, pengangguran turut serta mempengaruhi peningkatan tindak pidana tersebut. Oleh karena itu, maka diperlukan suatu sistem yang dapat melakukan prediksi kerawanan suatu wilayah terhadap tindak pidana pencurian sepeda motor beserta faktor-faktor yang mempengaruhinya.

Penelitian ini mengembangan model prediksi kerawanan wilayah terhadap tindak pidana pencurian sepeda motor dengan mengkombinasikan metode (Seasonal) ARIMA (SARIMA) dan metode Decision Tree CART. (S)ARIMA adalah metode peramalan berdasarkan data time series yang banyak digunakan untuk memprediksi ke masa yang akan datang. CART merupakan suatu metode pohon biner yang populer untuk melakukan klasifikasi yang dapat menghasilkan model atau aturan klasifikasi.

Hasil peramalan dengan metode (S)ARIMA yang dilakukan dengan masing-masing variabel menghasilkan model peramalan dan nilai error peramalan yang berbeda-beda berdasarkan pola data dari setiap variabel tersebut. Hasil klasifikasi dengan metode CART mendapatkan nilai akurasi sebesar 91,7\% untuk kota Yogyakarta dan 87,5\% untuk DIY. Berdasarkan hasil penelitian, peramalan (S)ARIMA dan klasifikasi CART dapat digunakan dalam memprediksi kerawanan wilayah terhadap tindak pidana pencurian sepeda motor.
\end{abstract}

Kata kunci-ARIMA, CART, kerawanan, Peramalan, Prediksi, Decision Tree

\section{Abstract}

Motorcycle theft is a criminal act including the most frequently occur in Indonesia. The growth of motor vehicles, especially motorcycles significantly in each year accompanied by the increasing theft of motorcycles in each year. In addition, population growth, unemployment participated affect the increase in such crime. Therefore, we need a system that can predict the susceptibility of an area to the crime of motorcycles theft as well as the factors that influence it.

This research develop models of predictive vulnerability area crime act of motorcycles theft using methods (S)ARIMA and CART. (S)ARIMA is a method of forecasting based on time series data that used to predict the future. CART is a popular method of binary tree to classify that produce classification rules.

Results forecasting (S)ARIMA conducted with each of the variables in a model forecasting and forecasting error value that varies based on the data pattern of each of those variables. The results of classification by CART scored an accuracy of $91.7 \%$ for the city of Yogyakarta and $87.5 \%$ for DIY. Based on the research, forecasting results (S)ARIMA and CART can be used to predict the vulnerability of the region to the crime act of motorcycles theft.

Keywords-ARIMA, CART, vulnerability, Forecasting, Prediction, Decision Tree 


\section{PENDAHULUAN}

$\mathrm{T}$ indak pidana pencurian kendaraan bermotor roda dua atau sepeda motor terjadi di seluruh wilayah Indonesia, tidak terkecuali di Daerah Istimewa Yogyakarta (DIY). Jumlah penduduk dan yang bermukim di DIY setiap tahun terus bertambah, baik dari Jawa maupun luar Jawa, menyebabkan pula makin meningkat jumlah kepemilikan dan pengguna kendaraan sepeda motor. Seiring dengan itu, semakin meningkat pula tindak pidana pencurian sepeda motor di daerah DIY. Menurut data BPS dan Kepolisian pada laporan Statistik tahun 2012 kenaikan angka kejahatan pencurian tersebut cenderung fluktuatif $[1,2]$.

Pencurian kendaraan bermotor merupakan salah satu tindak kriminal yang menonjol dari sisi tingkat kejadiannya di Indonesia (BPS dan Kepolisian). Dugaan penyebabnya ialah karena kendaraan bermotor merupakan sarana vital dengan mobilitas tinggi yang sangat diperlukan untuk kehidupan di era modern ini. Dengan semakin meningkatnya tindak pidana pencurian sepeda motor pada tiap tahunnya, maka diperlukan suatu sistem yang dapat melakukan prediksi terhadap perkembangan kendaraan bermotor roda dua dan tindak pidana pencurian sepeda motor beserta aspek lain yang memungkinkan berpengaruh terhadap peningkatan tindak pidana pencurian sepeda motor.

Salah satu parameter yang digunakan untuk melakukan prediksi terhadap kerawanan suatu wilayah adalah kasus, penduduk, pengangguran, kendaraan dan angkatan kerja. Alasan menggunakan variabel tersebut adalah variabel-variabel tersebut merupakan paramater awal yang digunakan untuk mendapatkan nilai-nilai yang dikonversi menjadi indikator-indikator kerawanan suatu wilayah terhadap tindak pencurian sepeda motor. Dari sumber data tersebut memperlihatkan adanya pola data dari waktu ke waktu untuk masing-masing variabel tersebut baik secara trend maupun musiman (seasonal).

Pada penelitian ini dilakukan kombinasi menggunakan metode (Seasonal) ARIMA dan klasifikasi decision tree CART untuk memprediksi kerawanan wilayah terhadap tindak pencurian sepeda motor. Pada penelitian ini, metode (Seasonal) ARIMA digunakan untuk melakukan prediksi terhadap data berkala (time series) untuk variabel jumlah kasus, kendaraan, penduduk dan pengangguran serta angkatan kerja. Hasil dari prediksi tersebut kemudian dihitung ke dalam indeks kasus, autho-theft rate, crime rate, crime index, kepadatan penduduk, dan indeks pengangguran yang digunakan untuk proses klasifikasi decision tree CART untuk menentukan atau memprediksi kerawanan suatu wilayah terhadap tindak pidana pencurian sepeda motor.

Pada penelitian sebelumnya yang berkaitan dengan metode ataupun permasalahan kriminal, metode ARIMA merupakan salah sati metode peramalan berdasarkan data time series yang baik untuk peramalan jangka menengah dan dapat digunakan untuk meramalkan untuk berbagai bidang. Peramalan dengan metode ARIMA digunakan dalam peramalan jangka pendek untuk kejahatan properti dan membantu pihak kepolisian dalam mengambil langkah antisipasi selanjutnya $[3,4,5,6]$. Sedangkan metode Decision Tree CART dilakukan untuk mengklasifikasikan suatu wilayah terhadap KLB/Non KLB penyakit campak [7] dan dapat untuk menentukan tingkat keparahan terhadap kecelakaan lalu lintas[8].

Penelitian ini mengusulkan pengembangan model prediksi kerawanan wilayah terhadap tindak pidana pencurian sepeda motor berbasis komputer. Hasil dari prediksi ini dapat digunakan untuk informasi awal untuk melakukan tindakan-tindakan tertentu yang dapat untuk menekan tindak pidana pencurian sepeda motor pada masa yang akan datang oleh pihak Kepolisian atau pihak yang terkait. 


\section{METODE PENELITIAN}

\subsection{Analisis Kebutuhan Sistem}

Analisa kebutuhan sistem meliputi, kebutuhan data, kemampuan dan fasilitas yang diharapkan, masukan data dan luaran sistem, proses persiapan data yang diteliti. Sistem yang akan dibangun merupakan sistem peramalan kerawanan wilayah terhadap tindak pidana pencurian sepeda motor.

\subsubsection{Data yang Digunakan}

Data yang digunakan pada prediksi ini berasal dari berbagai instansi antara lain untuk data kasus pencurian dari Direktorat Kriminal Umum POLDA DIY, Satrekrim Polresta Yogyakarta, data kendaraan bermotor dari Direktorat Lalu Lintas POLDA DIY, data penduduk dari Bagian Penduduk Biro Pemerintahan Setda DIY dan Data pengangguran dan angkatan kerja dari Dinas Tenaga Kerja dan Transmigrasi DIY serta BPS DIY. Data tersebut dalam kurun waktu Januari 2011 - Desember 2015 yang dihitung secara bulanan untuk wilayah DIY dan Kota Yogyakarta. Dengan demikian data yang digunakan sebanyak 5 tahun x 12 bulan x 2 wilayah $=120$ data per variabel $\times 5$ variabel $=600$.

\subsubsection{Preprocessing data}

Berikut adalah langkah-langkah yang dilakukan dalam preprocessing data yang dilakukan dalam klasifikasi dan prediksi [9].

a. Data Cleaning

Data yang diperoleh dari pihak kepolisian, Kependudukan DIY, Disnakertrans DIY dan BPS berupa print cetak atau dalam bentuk softcopy dalam bentuk bulanan dari tahun 20112015.

b. Analisis relevansi

Dalam proses ini, khususnya untuk jumlah kasus pencurian kategori yang termasuk dalam kasus pencurian di dalam penelitian ini meliputi pencurian motor (pasal 362 dan 363 KUHP), pencurian dengan pemberatan dan kekerasan (CURAT dan CURAS) serta penggelapan pada kendaraan bermotor roda dua[10].

c. Transformasi data

Dalam hal ini tidak dilakukan transformasi data terlebih dahulu akan tetapi transformasi dilakukan dalam proses stasionerisasi (jika dibutuhkan).

\section{2 Rancangan System}

Model sistem yang digunakan melibatkan 2 proses yang mempunyai fungsi masingmasing. Metode time series (Seasonal) ARIMA digunakan untuk melakukan peramalan terhadap nilai untuk periode ke depan, dalam penelitian ini akan dilakukan prediksi untuk 6 periode ke depan (Januari 2016 - Juni 2016). Sedangkan metode Decision Tree CART digunakan untuk melakukan klasifikasi kerawanan wilayah terhadap tindak pidana pencurian sepeda motor berdasarkan nilai yang dihasilkan dari proses peramalan. Bentuk arsitektur dari sistem yang akan dibangun dipaparkan pada Gambar 1. 


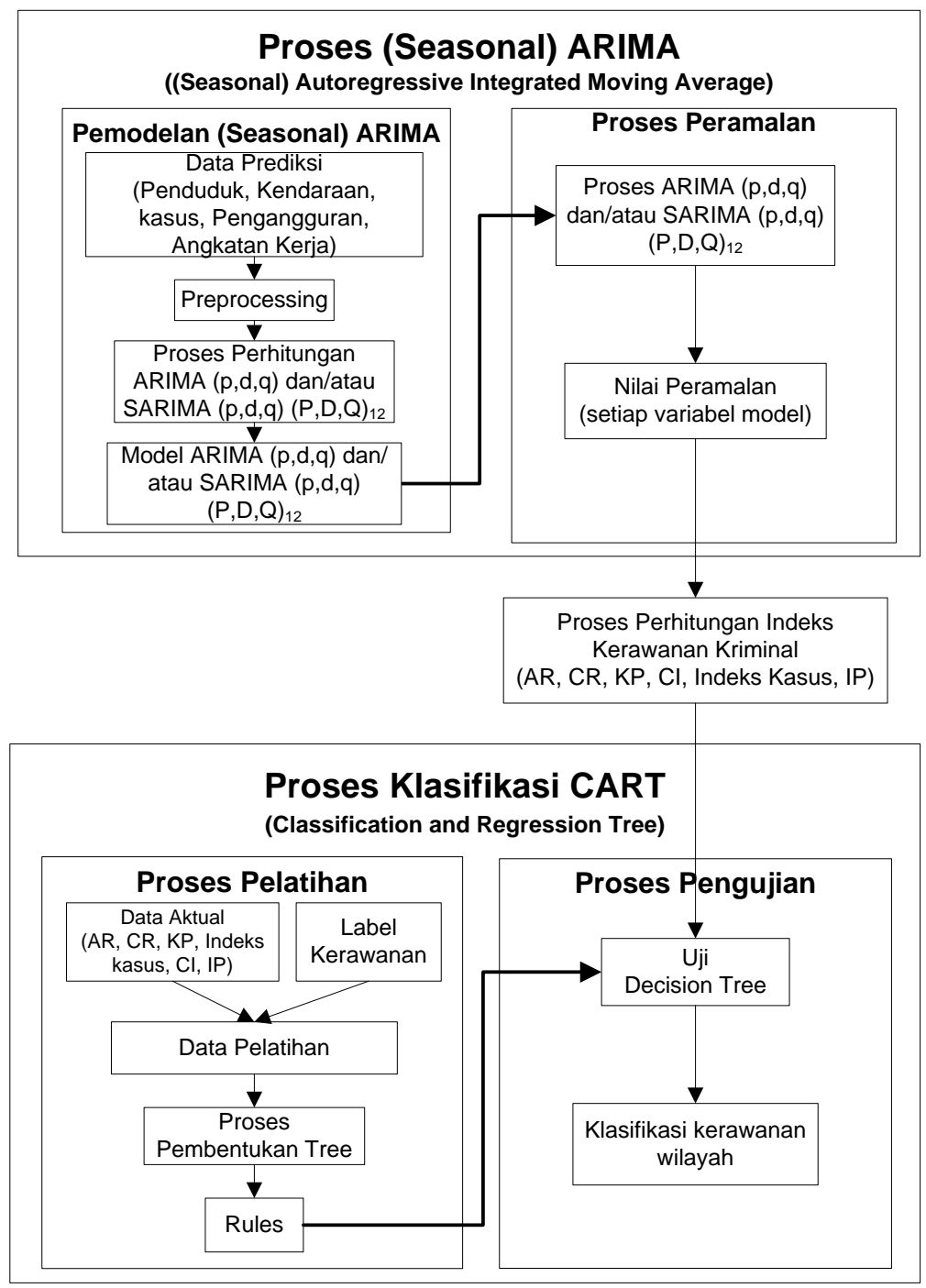

Gambar 1 Arsitekstur Sistem Peramalan

Sistem Prediksi yang akan dibangun menggunakan kombinasi dari dua metode yaitu Metode (Seasonal) ARIMA dan Metode Decision Tree CART. Metode (Seasonal) ARIMA digunakan untuk meramalkan data time series dari variabel jumlah kasus pencurian, jumlah kendaraan yang ada, jumlah penduduk, jumlah pengangguran dan jumlah angkatan kerja. Variabel-variabel tersebut akan diprediksi pervariabel berdasarkan bulan. Kemudian variabelvariabel tersebut dilakukan proses pemodelan, terlebih dahulu diawali dengan proses cek stasioner dalam varian dan mean kemudian plot ACF dan PACF untuk mendapatkan modelmodel (Seasonal) ARIMA yang mungkin selanjutnya dilakukan proses estimasi parameter dan cek diagnostik atau "white noise" untuk mendapatkan model (Seasonal) ARIMA terbaik yang selanjutnya digunakan untuk mendapatkan nilai peramalan dari masing-masing variabel. Maka diperoleh hasil peramalan berdasarkan model (Seasonal) ARIMA yang terbaik. Nilai-nilai peramalan tersebut selanjutnya digunakan untuk menentukan atau mendapatkan nilai indikator kerawanan wilayah terhadap tindak pidana pencurian sepeda motor yaitu autho-theft rate, indeks kasus, crime rate, kepadatan penduduk, crime index, indeks pengangguran.

Kemudian pada proses klasifikasi CART yang terdiri dari proses training dan testing. Sebelum proses tersebut dilakukan, terlebih dahulu menyiapkan data yang akan digunakan untuk proses training dan testing. Data untuk proses klasifikasi CART terdiri dari beberapa variabel yang dimasukkan ke dalam indikator kerawanan wilayah terhadap tindak pencurian 
sepeda motor yaitu yaitu autho-theft rate, indeks kasus, crime rate, kepadatan penduduk, crime index, indeks pengangguran dan stasus (label kelasnya). Selanjutnya langkah pelatihan pada CART yang dilakukan adalah membangun pohon keputusan dengan cara splitting kriteria. Kemudian membentuk pohon dan melakukan pembentukan rule. Proses selanjutnya adalah pengujian terhadap data hasil peramalan (Seasonal) ARIMA yang telah dihitung/dikonversi ke dalam nilai indikator kerawanan wilayah terhadap tindak pidana pencurian sepeda mtor yaitu autho-theft rate, indeks kasus, crime rate, kepadatan penduduk, crime index, indeks pengangguran. Data tersebut diuji ke dalam klasifikasi CART mengggunakan rule yang telah terbentuk untuk mengetahui kerawanan wilayah terhadap tindak pencurian sepeda motor pada suatu wilayah. Langkah selanjutnya adalah menghitung nilai akurasi CART dan melakukan pengujian model dengan menggunakan $K$-fold validation.

\section{3 (Seasonal) Autoregressive integrated moving average (SARIMA)}

Metode ARIMA adalah metode peramalan yang tidak menggunakan variabel independen sebagai pembanding sehingga perhitungan dilakukan menggunakan variabel dependen saja. ARIMA dikenal pula sebagai metode BOX JENKINS karena dikembangkan oleh G.E.P BOX dan G.M Jenkins pada tahun 1970. Model ARIMA dapat terjadi karena terdapat pembedaan/differencing dari data aslinya. Disebabkan oleh adanya proses differencing tersebut, model ARMA menjadi ARIMA karena ada penyisipan huruf I yang berarti integrative. Integrative tersebut menunjukan adanya proses differencing [11]. Secara umum, bentuk model ARIMA dengan orde $(\mathrm{p}, \mathrm{d}, \mathrm{q})$ dengan differencing sebanyak d diperlihatkan dalam persamaan $1[12,13]$.

$$
\emptyset_{p}\left(B^{p}\right)(1-B)^{d} Y_{t}=C+\theta_{q}\left(B^{q}\right) a_{t}
$$

model ARIMA dinotasikan menjadi.

\section{$\operatorname{ARIMA}(\mathbf{p}, \mathbf{d}, \mathbf{q})$} dengan :

$Y_{t} \quad=$ nilai variabel dependen pada waktu $t$;

$q \quad=$ orde model moving average;

$\theta_{q}\left(B^{q}\right)=\left(1-\theta_{1} B-\cdots-\theta_{q} B^{q}\right)$;

C = konstanta;

$$
\begin{array}{ll}
p & =\text { orde model autoregressive; } \\
\emptyset_{p}\left(B^{p}\right) & =\left(1-\emptyset_{1} B-\cdots-\emptyset_{p} B^{p}\right) \\
a_{t} & =\text { nilai residu pada waktu } t ; \\
d & =\text { banyaknya differensiasi; }
\end{array}
$$

Sedangkan model ARIMA dengan pengaruh seasonal (musiman) yang disebut dengan Seasonal ARIMA (SARIMA) dinyatakan pada persamaan $2[12,13]$.

$$
\Phi_{p}\left(B^{S}\right) \emptyset_{p}(B)(1-B)^{d}\left(1-B^{S}\right)^{D} Y_{t}=\theta_{q}(B) \Theta_{Q}\left(B^{S}\right) a_{t}
$$

dengan

$$
\begin{array}{ll}
\varnothing_{p}(B) & =\text { faktor AR tidak musiman } \\
\Theta_{q}(B) & =\text { faktor MA tidak musiman } \\
\Phi_{P}\left(B^{s}\right) & =\text { faktor AR musiman } \\
\Theta_{Q}\left(B^{s}\right) & =\text { faktor MA musiman } \\
\Phi_{p}\left(B^{s}\right) & =\left(1-\Phi_{1} B^{s}-\Phi_{2} B^{2 s}-\cdots-\Phi_{p} B^{P_{s}}\right) \\
\Theta_{Q}\left(B^{s}\right) & =\left(1-\Theta_{1} B^{s}-\Theta_{2} B^{2 s}-\cdots-\Theta_{Q} B^{Q s}\right)
\end{array}
$$

Secara umum, model Seasonal ARIMA dinotasikan sebagai berikut:

$$
\operatorname{SARIMA}(\mathbf{p}, \mathrm{d}, \mathbf{q})(\mathbf{P}, \mathbf{D}, \mathbf{Q})_{\mathrm{s}}
$$

dengan,

$\begin{array}{llll}P & =\text { orde musiman untuk AR, } & Q & =\text { orde musiman untuk MA } \\ D & =\text { banyak differensiasi, } & S & =\text { jumlah periode permusim }\end{array}$ 


\section{4 Classification and Regression Tree (CART)}

Salah satu metode data mining yang umum digunakan adalah Decision Tree. Decision Tree adalah struktur flowchart yang menyerupai tree (pohon) dengan setiap simpul internal menandakan suatu tes pada atribut, setiap cabang merepresentasikan hasil tes dan simpul daun merepresentasikan kelas atau distribusi kelas. Algoritma CART merupakan metode eksplorasi yang digunakan untuk melihat hubungan antara peubah respon dan peubah penjelas yang meliputi peubah nominal, ordinal maupun kontinu. Metode ini meliputi metode pohon klasifikasi dan pohon regresi. Metode pohon klasifikasi digunakan jika peubah responnya adalah peubah kategorik sedangakan pohon regresi digunakan jika peubah respon adalah kontinu.

Adapun langkah langkah pada algoritma CART adalah sebagai berikut [14]:

1. Susunlah calon cabang (candidate split). Penyusunan ini dilakukan terhadap seluruh variabel prediktor secara lengkap (exhaustive). Daftar yang berisis calon cabang disebut daftar calon cabang mukhtahir.

2. Menilai kinerja keseluruhan calon cabang yang ada pada daftar calon cabang mukhtahir dengan jalan menghitung nilai besaran kesesuaian.

3. Menentukan calon cabang manakah yang akan benar-benar dijadikan cabang dengan memilih calon cabang yang memiliki nilai kesesuaian terbesar. Setelah itu gambarkan percabangannya, jika tidak ada lagi node keputusan, pelaksanaan algoritma CART akan dihentikan. Namun jika masih terdapat node keputusan, algoritma dilanjutkan dengan kembali kelangkah ke dua, dengan terlebih dahulu membuang calon cabang yang telah berhasil menjadi cabang sehingga mendapatkan daftar calon cabang mukthahir baru.

\section{HASIL DAN PEMBAHASAN}

Dalam penelitian ini melakukan 2 proses yaitu peramalan dan klasifikasi. Proses pada (Seasonal) ARIMA dilakukan untuk mendapatkan nilai peramalan dan proses CART digunakan untuk melakukan klasifikasi terhadap nilai yang dihasilkan dari proses peramalan ARIMA. Setelah mendapatkan hasil dari proses klasifikasi CART dilanjutkan dengan proses pengujian model dari klasifikasi untuk mendapatkan nilai akurasi terbaik dari model yang dihasilkan dari klasifikasi tersebut.

\subsection{Peramalan (Seasonal) ARIMA}

Dalam proses peramalan (Seasonal) ARIMA yang menjadi hal yang utama ada menentukan pola atau model yang paling cocok berdasarkan data time series. Dengan demikian peramalan (Seasonal) ARIMA memerlukan sepenuhnya data historis (data masa lalu dan saat ini) untuk melakukan proses peramalan yang akurat. Dalam peramalan (Seasonal) ARIMA yang menjadi syarat penting adalah kestasioneran data dalam varians dan mean. Data yang stasioner mempunyai variansi data yang tidak terlalu lebar dan cenderung mendekati nilai rata-rata datanya. Dalam penelitian ini proses peramalan dilakukan untuk variabel kasus, kendaraan, penduduk dan pengangguran serta angkatan kerja.

Proses pemodelan dan peramalan metode (Seasonal) ARIMA menggunakan keseluruhan data yang ada dalam suatu wilayah yaitu $60 \times 4=240$ data per wilayah. Dari masing-masing variabel peramalan (Seasonal) ARIMA mempunyai model dan menghasilkan nilai peramalan yang berbeda. Untuk wilayah DIY, variabel kasus mempunyai MAPE $=0,197$, variabel kendaraan, MAPE $=0,0118$, untuk variabel penduduk, MAPE $=0,000897$ dan variabel pengangguran, nilai MAPE $=0,00603$ serta untuk angkatan kerja, nilai MAPE $=0,0027$. Sementara itu, kota Yogyakarta, variabel kasus mempunyai nilai MAPE $=0,233$, variabel kendaraan, MAPE $=0,0062$, untuk variabel penduduk, MAPE $=0,00068$ dan variabel pengangguran, nilai MAPE $=0,0042$ serta untuk angkatan kerja, nilai MAPE $=0,0016$. Hasil peramalan dengan metode ARIMA diperoleh diperlihatkan pada Tabel 1 untuk wilayah DIY dan Tabel 2 untuk wilayah kota Yogyakarta.

IJCCS Vol. 11, No. 2, July $2017: 119-130$ 
Tabel 1 Hasil Peramalan (Seasonal) ARIMA Wilayah DIY

\begin{tabular}{|c|c|r|r|r|r|c|}
\hline Tahun & Bulan & Kasus & Kendaraan & Penduduk & Pengangguran & $\begin{array}{c}\text { Angkatan } \\
\text { Kerja }\end{array}$ \\
\hline 2016 & Januari & 51 & 1.888 .573 & 3.628 .960 & 62.544 & 2.052 .081 \\
\hline & Februari & 52 & 1.919 .204 & 3.635 .514 & 59.005 & 2.068 .262 \\
\hline & Maret & 52 & 1.949 .828 & 3.642 .067 & 56.939 & 2.083 .443 \\
\hline & April & 52 & 1.980 .447 & 3.648 .621 & 54.873 & 2.098 .224 \\
\hline & Mei & 52 & 2.011 .059 & 3.655 .174 & 52.808 & 2.112 .848 \\
\hline & Juni & 52 & 2.041 .666 & 3.661 .728 & 50.742 & 2.127 .408 \\
\hline
\end{tabular}

Tabel 2 Hasil Peramalan (Seasonal) ARIMA Kota Yogyakarta

\begin{tabular}{|c|c|r|r|r|r|c|}
\hline Tahun & Bulan & Kasus & Kendaraan & Penduduk & Pengangguran & $\begin{array}{c}\text { Angkatan } \\
\text { Kerja }\end{array}$ \\
\hline 2016 & Januari & 17 & 356.164 & 409.495 & 13.517 & 229.257 \\
\hline & Februari & 18 & 358.939 & 409.631 & 13.764 & 229.206 \\
\hline & Maret & 19 & 361.503 & 409.767 & 13.986 & 229.744 \\
\hline & April & 20 & 363.393 & 409.902 & 14.209 & 229.646 \\
\hline & Mei & 21 & 364.656 & 410.038 & 14.431 & 228.980 \\
\hline & Juni & 22 & 366.897 & 410.174 & $14 / 653$ & 227.751 \\
\hline
\end{tabular}

Sedangkan grafik plot hasil peramalan (Seasonal) ARIMA untuk wilayah diperlihatkan pada Gambar 2, 3, 4, 5 dan 6.

: Data Aktual vs Hasil Peramalan kasus Pencurian Sepeda Motor Wila)

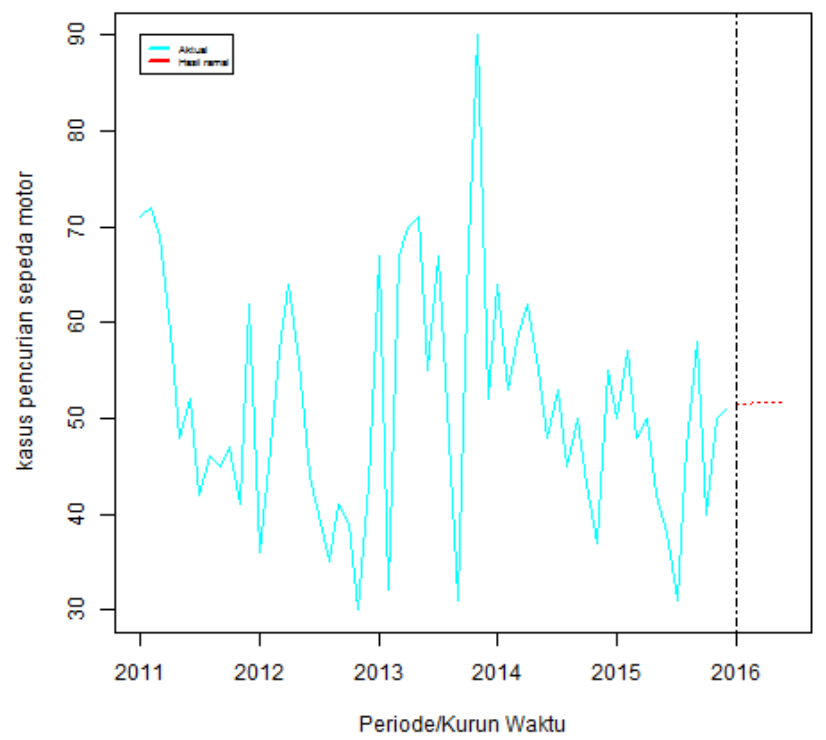

Gambar 2 Hasil Peramalan Kasus Wilayah DIY 
Plot Data Aktual vs Hasil Peramalan penduduk DIY

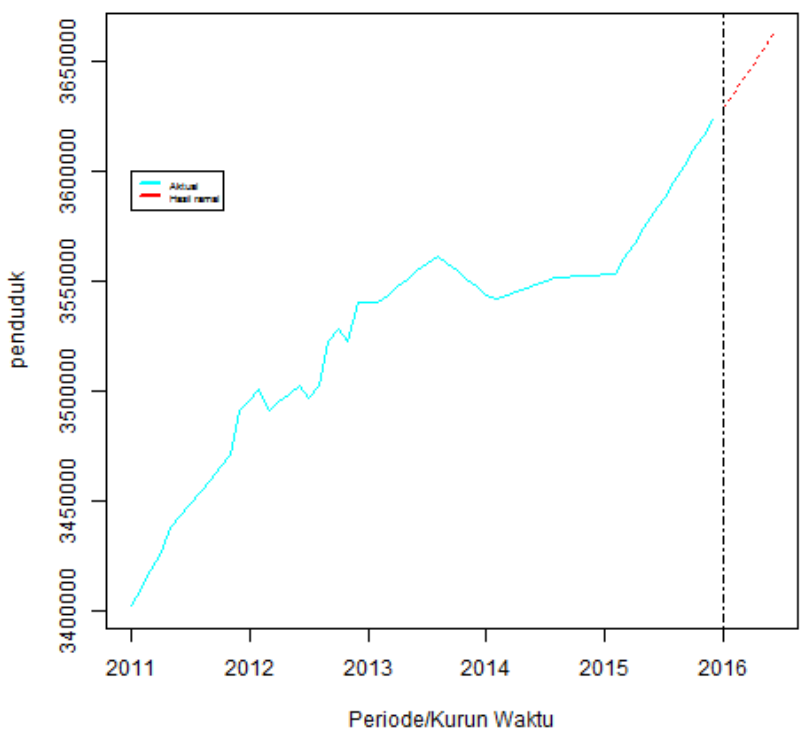

Gambar 3 Hasil Peramalan Penduduk Wilayah DIY

Plot Data Aktual vs Hasil Peramalan kendaraan DIY

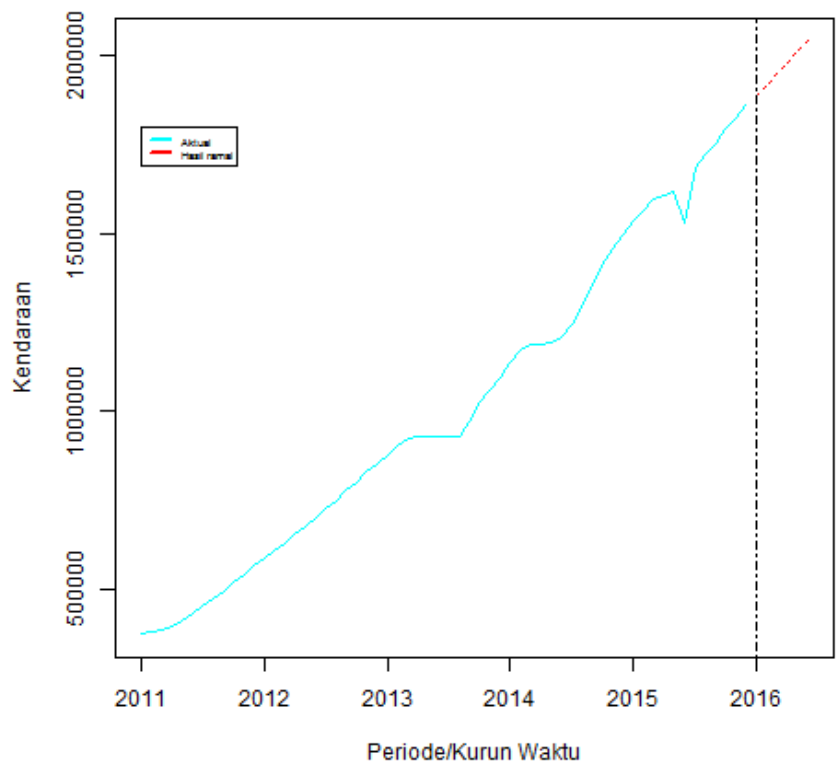

Gambar 4 Hasil Kendaraan Wilayah DIY 


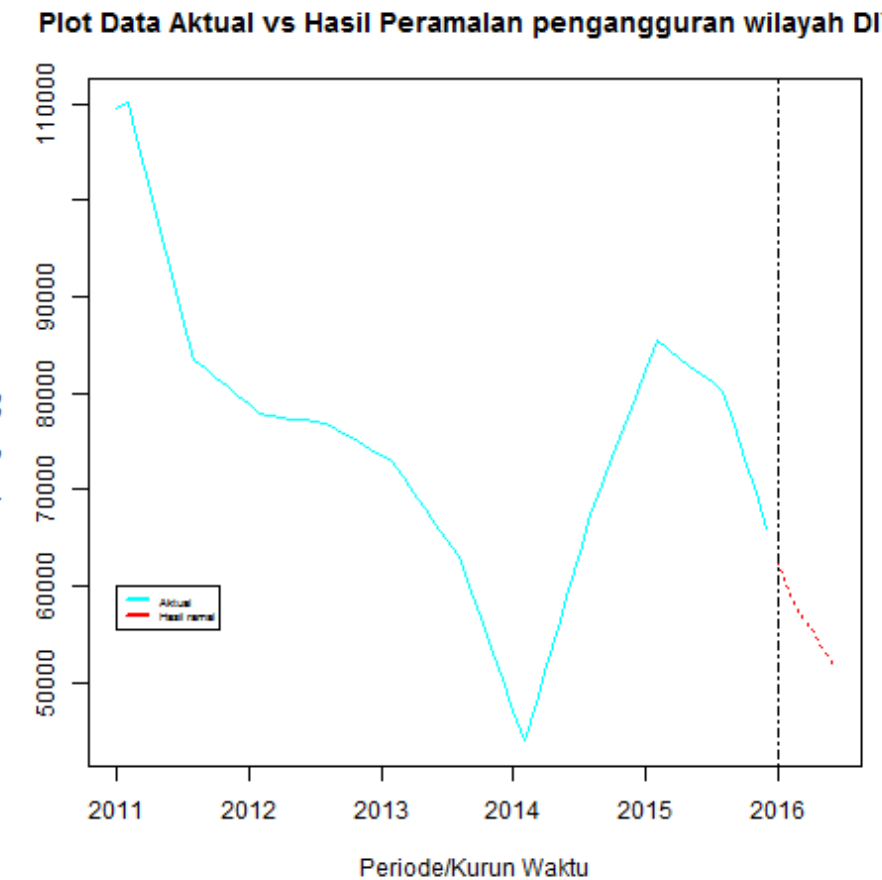

Gambar 5 Hasil Peramalan Pengangguran Wilayah DIY

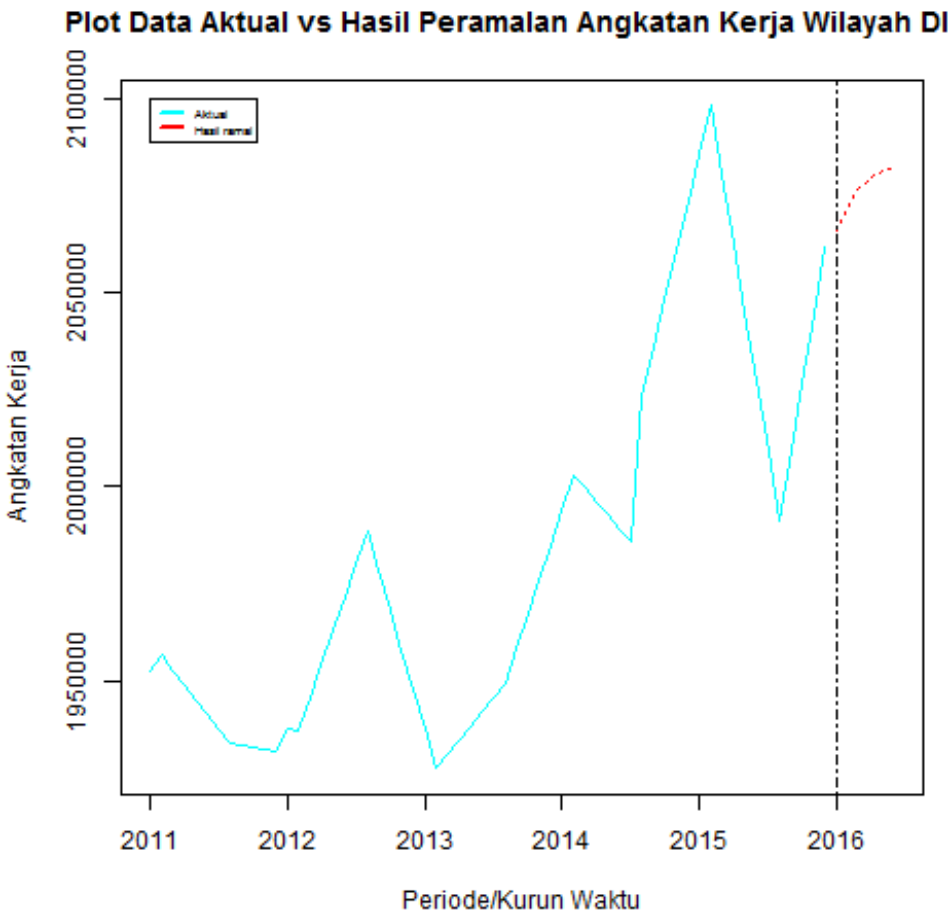

Gambar 6 Hasil Peramalan Angkatan kerja Wilayah DIY

Keterangan:

: Hasil Peramalan

: Data Aktual 


\subsection{Klasifikasi Decision Tree CART}

Kemudian setelah mendapatkan nilai peramalan untuk periode yang mendatang melalui peramalan (Seasonal) ARIMA maka selanjutnya hasil peramalan dari masing-masing variabel peramalan data-data tersebut akan dihitung atau dikonversi ke dalam nilai-nilai indikator kerawanan wilayah yaitu autho-theft rate, crime rate, crime index, indeks pengangguran dan kepadatan penduduk [15] yang digunakan untuk memprediksi atau menentukan kelas kerawanan wilayah berdasarkan hasil peramalan (Seasonal) ARIMA. Setelah dihitung, selanjutnya data-data tersebut digunakan untuk memprediksi atau menentukan kelas kerawanan suatu wilayah terhadap tindak pencurian sepeda motor dengan menggunakan rule yang terbentuk pada proses training CART. Setelah dilakukan pengujian terhadap CART maka selanjutnya dihasilkan hasil seperti pada Tabel 3.

Tabel 3 Hasil Klasifikasi Kerawanan Wilayah

\begin{tabular}{|c|c|c|c|}
\hline \multirow{2}{*}{ Tahun } & \multirow{2}{*}{ Bulan } & \multicolumn{2}{|c|}{ Wilayah } \\
\cline { 3 - 4 } & & DIY & Kota Yogyakarta \\
\hline 2016 & Januari & Rendah & Rendah \\
\hline & Februari & Rendah & Sedang \\
\hline & Maret & Rendah & Sedang \\
\hline & April & Rendah & Sedang \\
\hline & Mei & Rendah & Sedang \\
\hline & Juni & Rendah & Tinggi \\
\hline
\end{tabular}

Hasil klasifikasi untuk tingkat kerawanan wilayah yang dilakukan oleh metode Decision Tree CART mendapatkan nilai akurasi sebesar $91,7 \%$ untuk wilayah kota Yogyakarta dan nilai akurasi sebesar $87,5 \%$ untuk wilayah DIY.

\section{KESIMPULAN}

Berdasarkan latar belakang, rumusan masalah dan hasil penelitian yang diperoleh, maka dapat disimpulkan bahwa hasil penelitian ini adalah:

1. Proses peramalan metode (Seasonal) ARIMA dilakukan per wilayah secara terpisah yaitu wilayah DIY dan kota Yogyakarta untuk 6 periode ke depan;

2. Nilai pengukuran error peramalan (Seasonal) ARIMA masing-masing variabel. Untuk wilayah DIY, variabel kasus mempunyai $\mathrm{MAPE}=0,197$, variabel kendaraan, MAPE $=$ 0,0118 , untuk variabel penduduk, MAPE $=0,000897$ dan variabel pengangguran, nilai MAPE $=0,00603$ serta untuk angkatan kerja, nilai MAPE $=0,0027$. Sementara itu, kota Yogyakarta, variabel kasus mempunyai nilai MAPE $=0,233$, variabel kendaraan, MAPE $=0,0062$, untuk variabel penduduk, MAPE $=0,00068$ dan variabel pengangguran, nilai MAPE $=0,0042$ serta untuk angkatan kerja, nilai MAPE $=0,0016$

3. Faktor-faktor yang mempengaruhi klasifikasi kerawanan wilayah terhadap tindak pidana pencurian sepeda motor untuk wilayah DIY yaitu, crime rate (CR), crime index (CI), indeks kasus (IK) dan kepadatan penduduk (KP). Sedangkan untuk wilayah Kota Yogyakarta, kerawanan wilayah terhadap tindak pidana pencurian sepeda motor dipengaruhi oleh faktor-faktor antara lain, crime rate $(\mathrm{CR})$, crime index $(\mathrm{CI})$, indeks kasus (IK) dan kepadatan penduduk (KP).

4. Hasil klasifikasi untuk kerawanan wilayah yang dilakukan oleh metode Decision Tree CART mendapatkan nilai akurasi sebesar 91,7\% untuk wilayah kota Yogyakarta dan nilai akurasi sebesar $87,5 \%$ untuk wilayah DIY. 


\section{SARAN}

Dari hasil penelitian ini, terdapat beberapa hal yang perlu ditambahkan dan dikembangkan dalam proses peramalan dan klasifikasi, antara lain:

1. Perlu kecermatan dan keakuratan dalam identifikasi model peramalan ARIMA;

2. Peramalan data time series dalam permasalahan dalam penelitian ini dapat dikembangkan dengan menggunakan atau menerapkan metode peramalan data time series lainnya seperti ARIMAX, JST dan sebagainya serta mengkombinasikan variabelvarieabel yang ada menjadi suatu metode multivariate ARIMA dan sebagainya;

3. Proses klasifikasi juga dapat dikembangkan menggunakan atau menerapkan metode klasifikasi seperti Bagging CART, ID3 dan lainnya;

4. Pengembangan metode lain dalam hal peramalaan perlu/dapat dilakukan dalam proses peramalan dan penentuan tingkat kerawanan tindak pidana pencurian sepeda motor atau pada kasus kriminal lainnya

\section{DAFTAR PUSTAKA}

[1] Badan Pusat Statistik, 2013. Statistik Kriminal. www.bps.go.id.

[2] Badan Pusat Stastistik Daerah Istimewa Yogyakarta, 2015. Statistik Politik dan Keamanan.www.jogja-bps.go.id.

[3] Bellaniar, M, 2014. Peramalan Demam Berdarah Dengue dengan menggunakan Metode SARIMA dan Artificial Neural Network. Thesis. UGM: Yogyakarta.

[4] Chen, P., Yuan, H., and Shu, X, 2008. Forecasting Crime Using the ARIMA Model. Fifth International Conference on Fuzzy Systems and Knowledge Discovery, Jinan Shandong, 627-630.

[5] Noor, N.M.M., dkk, 2011. A Framework of Decision Support for Crime Forecasting in Malaysia. Journal Recent Researches in Applied Mathematics and Informatics. ISBN: 978-1-61804-059-6.

[6] Permanasari, A.E, Hidayah, I dan Bustoni, I. A, 2013. SARIMA (Seasonal ARIMA) implementation on time series to forecast the number of Malaria incidence. 2013 International Conference on Information Technology and Electrical Engineering (ICITEE), Yogyakarta, pp 203-207.

[7] S. Sulistyowati and E. Winarko, "Peramalan KLBCampakMenggunakanGabunganMetode JST Backpropagationdan CART," IJCCS (Indonesian J. Comput. Cybern. Syst., vol. 8, no. 1, pp. 49-58, 2014 [Online]. Available: https://jurnal.ugm.ac.id/ijccs/article/view/3495. [Accessed: 16Mar-2017]

[8] Chang, L. Y dan Wang, H,W, 2006. Analysis Of Traffic Injury Severity: An Application Of Non Parametric Classification Tree Techinques. Journal Accident Analysis Dan Prevention, Vol. 38, hal 436-444 diakses dari www.elsevier.com.

[9] Han, J dan Kamber, M, 2001. Data Mining:Concepts And Techniques. Morgan Kaufmann: San Fransisco, USA. 
[10] Kitab Undang-Undang Hukum Pidana (KUHP) Indonesia.

[11] Santoso, S, 2009. Bussiness forecasting - Metode peramalan bisnis masa kini dengan minitab dan SPSS. Elex Media Komputindo: Jakarta.

[12] Rosadi, D,2014. Analisis Data Runtun Waktu dan Aplikasinya dengan R. UGM Press:Yogyakarta.

[13] Wei, W.W.S, 2006. Time series Analysis: Univariate and Multivariate Methods Second Edition. Pearson Addison Wesley : USA.

[14] Larose, D, 2005. Discovering Knowledge In Data An Introduction To Data Mining. Wiley Interscience: USA.

[15] Badan Pusat Statistik, 2014. Statistik Kriminal Tahun 2014. www.bps.go.id. 